\title{
ENGLISH BORROWINGS IN INDONESIAN NEWSPAPERS
}

\author{
Iwan Fauzi \\ Universitas Palangkaraya \\ iwanfauzi09@yahoo.com
}

\begin{abstract}
This study represents a corpus-based study of English loan words in Bahasa Indonesia used by three foremost newspapers in Indonesia (Kompas, Koran Tempo, and Media Indonesia). There are 19,494 loan tokens of 3,538 loan types extracted from 3,671 texts published online on those media during around three months ranging from 1 April to 24 June 2012. This study compares two basic typologies of borrowing - established and non-established loans. Attestations are looked into in this study proving the evidence that the borrow ability of nouns is higher than otherword categories, linguistic typology of borrowing motivates linguistic adaptation, and word categories give a significant contribution to motivate linguistic adaptation as well.
\end{abstract}

Keywords: Sociolinguistics, borrowing, loanwords, morphological integration, linguistic adaptation

In the era of free trade, the use of English as a global language in Indonesia especially in big cities such as Jakarta, Medan, Semarang, and Surabaya has not only become a must for the settlers but also is getting more frequent. Emilia and Widiadana (in The Jakarta Post July 2, 2000) regard that "English has penetrated Bahasa Indonesia and it seems there is no stopping it, not a day passes in a metropolitan city like Jakarta in which English is not heard, although it might not be spoken correctly". They further point out that Indonesian people ranging from the president of Indonesia to business executives, celebrities, housewives, and teenagers are adopting English phrases in their daily linguistic interactions.

Public figures, for instance, who are always in the media spotlight, are parts of the trend borrowing English words as well. They speak both languages in mixed utterances, fusing English words with Indonesian ones while speaking at seminars, on talk shows or when being interviewed by journalists. This trend is followed by news media like newspapers and magazines which do not stay behind in using massively borrowing English words. Consider the following examples of borrowing English words inserted into Bahasa Indonesia from national newspapers in Indonesia.

(1) Sesuai prinsip checks and balances yang menyemangati perubahan konstitusi ...

According principle REL motivate amendment constitution

In accordance with the principle of checks and balances motivating the constitution amendment...

(Kompas, Friday 01 September 2006)

(2) ... dan sejauh ini Golkar tidak mampu mengcounter-nya.

... and far DEM Golkar NEG able PREF-PRON

... and so far Golkar cannot counter it. (Media Indonesia, Tuesday 26 August 2008)

(3)AS telah menjadi inti kekuatan status quo.

US PERF become main power

US has become the main power of status quo. (Koran Tempo, 29 July 2004)

The frequent occurrences of mixed sentences as in these examples inspired the writer to investigate thecase of English borrowings. 
In this paper, the writer prefers to use the term "borrowing" to indicate the process of loan words borrowed from one language to another language, and more in particular, most sociolinguistic researchers term such phenomenonas a lexical borrowing. In this article, the terms borrowing and loan word are regarded equal and are used interghangeably henceforward.

The term 'borrowing' or 'loan word' according to Mesthrie \& Leap (2000) is a technical term for the incorporation of an item from one language into another. These items could be (in terms of decreasing order of frequency) words, grammatical elements or sounds. Poplack et al. (1988) specifically indicate that lexical borrowing involves the incorporation of individual second language (L2) words (or compounds functioning as single words) into the first language (L1) discourse, the host or recipient language, usually phonologically and morphologically adapted to conform with the patterns of that language, and occupying a sentence slot dictated by its syntax. In addition, Grosjean (1995) defines that borrowing can also take place when a 'word or a short phrase' (usually phonologically or morphologically) is borrowed from the other language or when the 'meaning component' of a word or an expression in the foreign language is expressed in the base language.

In multilingual environments, the definition of borrowing overlaps with the phenomenon of codeswitching. In fact, sociolinguists have precisely defined the two terms. Poplack's depiction of codeswitching stresses its difference from borrowing as she states that "code switching is the juxtaposition of sentences or sentence fragments, each of which is internally consistent with the morphological and syntactic (and optionally, phonological) rules of the language of its provenance" (in Onysko 2007:36). Borrowing, on the other hand, is primarily a lexical process that is accompanied by morphological and partly phonological assimilation in the receptor language (ibid). Clyne stresses the fact that codeswitching and borrowing form a continuum of usage (2003:71). However, while "codeswitching is employed for both singleword and multi-word elements, borrowing is limited to the former" (ibid). Furthermore, borrowings constitute part of the lexicon of the matrix language whereas codeswitches belong to the embedded language lexicon (ibid).

More precisely King argues that "intuitively, codeswitches and borrowings would appear distinct: the former is the product of two grammars, the later of one" (2000:86). From these definitions, Onysko (2007:36) summarizes that borrowings can be distinguished from codeswitching by their morphosyntactic integration into the receptor language. Thus, borrowings are paradigmatically incorporated and follow the syntagmatic relations of the receptor language whereas codeswitches retain the paradigmatic markings and the syntagmatic relationship from their original language.

To name that lexical borrowings is one of linguistic phenomenon, in many studies sociolinguists prefer to distinguish two types of borrowing, 'established borrowings' and 'nonce borrowings'. Poplack \& Meechan (1995:200) defined established borrowings as lexical items that are morphologically, syntactically and often phonologically integrated into the borrowed language. Nonce borrowing is defined as 'incorporation' of a singly uttered word from another language by a single speaker in some reasonably representative corpus.

Nonce borrowing, according to Poplack \& Meechan (1998), tend to involve lone lexical items. These are mostly content words, which display similar morphological, syntactic and phonological features as their established counterpart, borrowings. The only difference is that they are neither recurrent nor widespread. In this respect, Sankoff et al. (1990) suggest that the two kinds are best distinguishable by the degree of syntactic and morphological integration of the loanword into the host language. In Bahasa Indonesia, for instance, the creation of Indonesian nouns with the addition of the ending-si is regarded mostly 
as established borrowings of Dutch (from -tie) e.g. politie - polisi, informatie - informasi, etc., and these borrowings have been established by their incorporation into Kamus Besar Bahasa Indonesia (Indonesian Dictionary) a very long time ago. Otherwise, some Indonesian borrowed words differ from theirborrowed language (let's say English), /c/, / ch/ changing to /k/ e.g., claim-klaim, complaint-komplain, corpus-korpus, champion-kampiun, etc. These loan words are regarded as nonce borrowings since they are neither recurrent nor widespread. In this study, the writer prefers to name them as non-established loans because formally they are still not recognized as loan words by the Indonesian Dictionary.

Since Bahasa Indonesia has many loan words used, some having become established borrowings but some having not. Poplack and Meechan (1995:200) differentiate both types of borrowing in which established borrowingsare defined as lexical items that are morphologically, syntactically and often phonologically integrated into the borrowed language, and non-established borrowings are defined as the 'incorporation' of a singly uttered word from another language by a single speaker in some reasonably representative corpus. In this case, non-established borrowings, according to Poplack \& Meechan (1998) tend to involve lonelexical items.

From these citations, it is implied that established borrowings are words integrated into the borrowing language and non-established borrowings are words unintegrated into the borrowing language. In relation to this study, it is clear that the established borrowings are the words which have been integrated into Bahasa Indonesia (BI) becoming a part of the language and no longer treated as English. Then, nonestablished borrowings are words which still are not part of the BI vocabulary, and these words are also still treated as English. More simply, when the borrowings are found in the Indonesian Dictionary, these borrowings are regarded as 'established loans'. Otherwise, words from the English language which are not mentioned in the Indonesian Dictionary are regarded as 'non-established loans'. This is a workable definition to provide a clear demarcation between established and nonestablished borrowings.

Words borrowed from one language into another language are mostly contents words because they carry meaning. In terms of hierarchy of borrow ability, van Hout \& Muysken (1994:14) state the following:

The words of a language are loose elements but at the same time they are part of a system; the lexicon itself is partly structured and the context in which words occur in the sentence may manifest themselves in the fact that some categories appear to be borrowed more easily than others at least are borrowed more frequently than others.

This fact was proven by Haugen (1950) as mentioned in Muysken (2000:74), who arrived at the following hierarchy:

nouns - adjectives - verbs - prepositions - coordinating conjunctions - quantifiers determiners - free pronouns - clitic pronouns - subordinating conjunctions

According to this perspective, nouns are borrowed more than verbs, verbs more easily than adjectives, and so on. Muysken (2000:7879) adduces three independent arguments on an English borrowing hierarchy in Tamil language. First, English pronouns are never inserted since pronouns rank low on these hierarchies. Second, there are never any English determiners, and other prenomial elements such as demonstratives and quantifiers accompanying the English noun. Third, the English nouns follow roughly the same dative and accusative case marking patterns, also quantitatively, as Tamil nouns.

However, languages vary on the borrow ability hierarchy. Despite differences in the duration of a language contact and the contact languages involved the common hierarchy is that nouns are the most frequently borrowed followed by either adjectives or verbs, followed by other word classes (Shamimah, 2006). Referring 
to van Hout \& Muysken (1994:42), “A very important factor involves one of the primary motivations for lexical borrowing, that is, to extend the referential potential of a language. Since reference is established primarily through nouns, these are the elements borrowed most easily". To what extent the borrow ability hierarchy of English applied to BI is also attested in the findings of this study.

The most important issue in lexical borrowing is how the language borrowed becomes established in the receptor language. To borrow foreign words (to name some, such as Dutch, English, and Arabic), BI has rules to treat the adaptation of the loan words. Moeliono et al. (2005) observed that at least there are four processes of borrowing adaptation into BI: (1) borrowing by adapting the spelling and the pronunciation, 'camera' à kamera; 'microphone' à mikrofon; (2) borrowing by adapting the spelling and without adapting the pronunciation,'file' affail; (3) borrowing without adapting the spelling but with adapting the pronunciation, 'bias' àbias and (4) borrowing without adapting the spelling and the pronunciation, 'golf'àgolf. These four types of adapted borrowing are what it is mentioned in the forewords as 'established' loanwords.

Some studies investigated English loan words in newspapers. Herein, the writer notices two essential studies by Roksana Bibi Abdullah (1995) and Shamimah Binti Haja Mohideen (2006) which both concerned with English loan words borrowed into the Malay language on Malay newspapers, plus one study investigated by Sundari Liando (2005) studying the types of English loan words found in an Indonesian newspaper.

Roksana Bibi Abdullah (1995) who studiedEnglish loan words into Malay in Singapore analyzed two popular Bahasa Melayu (BM) newspapers namely Berita Harian (printed on weekdays) and Berita Minggu (printed on weekends) from November to December 1994. The focus of her study was to identify English loan words with Malay equivalents, which have not been written in Ddictionary of Dewan Bahasa dan Pustaka (a dictionary of $\mathrm{BM}$ which is popularly so-called in Malaysia as Kamus Dewan). In her study, she reported that journalists of the Berita Harian group (including Berita Minggu) did not considerate using English loan words in three ways. First, news writers used English loan words when there were Malay expressions available, for example: 'trainer' for jurulatih, 'reviu' for ulasan, 'instruktor' for pengajar. Second, the news writers used accepted English loan words, but did not observe the Romanized Malay system of spelling, for example: 'scenario', 'komandar', etc. Third, the news writers used accepted loan words, but they differed from BM morphology, for example: 'banker', 'perbankan', 'analgesik', etc. Of the three types of usage, the first was the most widespread. From her study, she reported that $65 \%$ of the English words have BM equivalents which mean that the effectiveness of BM words had lost its value in conveying the intended messages.

The other study of English loan words in BM media was investigated by Shamimah Binti Haja Mohideen. In specific, she focused on three aspects: identifying the kinds of loan words used in BM, analyzing the writers' purpose of using the English lexical items in their BM articles, and finding out the writers' attitude and the readers' response towards the use of English loan words with BM equivalents. In her findings, Shamimah (2006) reported that types of English word borrowed into BM are mostly dominated by nouns $(78.73 \%)$. The two other categories were adjectives $(16.60 \%)$ and verbs (4.67\%); no adverbs were borrowed. The characteristics of English loan words reported from the findings cover three types of loans namely (a) words without equivalents, (b) words with close equivalents (English loans with close but not precise BM equivalents), and (c) words with equivalents.

BM and BI actually have no difference in their lexicons. The study about English loan words in BI was done by Sundari Liando (2005). She studied the types of English loan words found 
in an Indonesian newspaper, i.e., Jawa Pos under the rubric section of "Komunikasi Bisnis". The aim of her study was to find out whether English loan words found in Komunikasi Bisnis section of Jawa Pos had been in accordance with the spelling system of BI. In brief, she found that there are 233 types of English loan words in Komunikasi Bisnis section of Jawa Pos. Those are under three characteristics of loan i.e., simple word (the spelling is not adapted to BI spelling system but the pronunciation, or the other way round), complex word (both spelling and pronunciation are adapted to BI spelling system), and translated word (loan word is translated into the BI lexicon). From her findings, there were $27.04 \%$ English loan words which were simple words; $69.96 \%$ English loan words were complex words, and 3.00\% English loan words belonged to translated words. Subsequently, she found that the adaptation of loan words to BI happened most frequently in both the spelling and the pronunciation. In regard to the BI spelling system, she also found that $99.14 \%$ of English loan words were in accordance with the BI spelling system. From her study, the writerof this study speculates that more than half of the English business lexicons inBIcontexts are established borrowings and almost one hundred percent of such kind of loans is integrated into the BI linguistic systems.

In regard tothis study, the writer has three objectives to his investigation; (1) to investigate borrowability hierarchy of English loanwords into $\mathrm{BI}$; (2) to investigate whether there is a difference between established and non-established loan in their word class distribution of the lexical borrowings occurred in written Indonesian news; and (3) to investigate whether the lexical borrowings morphologically integrated or adapted into BI context.

Concerning to the three aims, the writer delimits his coverage of English borrowing forms.First, this study did not include English borrowing forms such as letters of the alphabet to name abbreviating terms (e.g., HP for "Hand Phone"), and proper names which mainly consist of English names of brands, companies, products, and buildings. Such borrowings were excluded from the data processing. Moreover, this study did not treat phonetic-phonological integration since the corpus used did not consist of spoken utterances. Hence, the writer only dealt with morphological and orthographical adaptation because they can be defined on the basis of written texts.

Second, the writer chose only three national papers become source of data, named Kompas, Media Indonesia, and Koran Tempo. These three newspapers are regarded to be representative for the data since they are widespread all over the countryand have online pages on internet. Their readers range from the ordinary people, students, businessman, educators, and employees to state officers. Meanwhile, the news contents are provided in a common language (the standard BI) which everybody is able to understand.

To review shortly, for instance, Kompas began to publishon June 28, 1965.This newspaper was established in Central Jakarta with the circulation of 4.800 copies. Since 1969, Kompas had dominated the national newspaper circulation. Then, in 2004its daily circulation was up to 530.000 copies. The readers of this newspaper today are roughly up to 2.25 million people all over Indonesia. Then, Media Indonesia is a daily newspaper published and established in Jakarta as well. It was firstly published in19 January 1970. Some assume that Media Indonesia is to be regarded as the second largest daily newspaper in Indonesia following Kompas. Last, Koran Tempo is one of Indonesian newspapers published in the capital. Before publishing a newspaper, Tempo was well-known as Majalah Tempo (Tempo Magazine). The first edition of Majalah Tempo was published in March 1971. However, this magazine had ever been banned by the government in 1982 and 1994 which made this media stopping to publish. Then, it returned to publish in 6 October 1998.Tempo finally launched its newspaper edition starting from 2 April 2001 named Koran Tempo. Today, it 
has a circulation roughly ranging from $100,000-$ 200,000 everyday. Its readers spreaded over the country are counted as approximately in the range of 300,000-600,000.

This is not exaggerated to say that the three papers have wide coverage in circulation. They might be said to be the pioneers of printed media in Indonesia. Therefore, they are more representative in using the formal BI in news media since their daily publication has been more than 20 years, including the Sunday edition. And most importantly, today they go with online publication so that it is easier for their readers to reach them anytime and anywhere.

\section{METHOD}

The data of this study were taken from a corpus made by the writer in 2012 . The corpus was taken from online news texts available on three Indonesian newspapers namely Kompas, Media Indonesia, and Koran Tempo in the period of around three months, from 1 April to 24 June 2012. In collecting the data, firstly the writer decided which topics were taken before downloading texts on the topics. There were 12 topics decided to be taken from the three papers, such as Telecommunication E technology, Economic $\mathcal{E}$ business, Politic $\mathcal{E}$ governance, Law $\mathcal{E}$ crime, Sport, Health $\mathcal{E}$ medicine, Music E entertainment, Fashion $\mathcal{E}$ clothes, Transportation, Environment, and Food $\mathcal{E}$ drink. To obtain texts of intended topic, the writer used a computer programme named wget with the parameter $-r$ with the "level 1". It is called wget where it stands for "world-wide-web get" which is the way to link to the web intended. To get the page he asked for,he used-r or minus rof the level 1to get only the pages which were linked directly.

After obtaining the pages, a computer software programme named GNU Aspell 0.50 Indonesian Dictionary Packageof version 1.2-0 was run to elicit English borrowings, both established and non-established loans. This software programme recognizes accepted BI word forms including many established borrowings. The result of data elicititation was a list of words with recognized as non-BI with their frequencies including content words, function words, and also word with affixes. In this case, the writer rechecked this list of words by hand to select all those words that represent English borrowings.

In making database, the writer listed all words which were extracted from his corpus in MS-excel sheets.From the database, the writergrouped the words identified as loan types (established versus non-established loans) according to their word classes to find out the borrow ability hierarchy. Next, the writerseparated the loan words in the database by grouping them according to their lexical integration or adaptation. Heshould make a precise demarcation of lexical integration between established loans and non-established loans since both have different ways of adaptation.

In data analysis, the writercompared the distribution of lexical borrowings according to nouns, verbs, adjectives and adverbs in the basis of the two types of borrowing. From the frequency distribution, the writermight find out what types of borrowing, which word classes and whether there is any significant difference of borrowability between established and nonestablished loans. The analysis was done through a statistical non-parametric test, namely chi-square test. In relation to the linguistic adaptation, the analysis compared the characteristics of adaptation and their distributions in established and non-established loans.

\section{FINDINGS}

The corpus was successfully made by extracting 3,671 articles from those three journals covering roughly 1,041,197 words. Koran Tempo had the highest number of articles with 1,428 texts covering 525,074 words, followed by Kompas with 1,264 articles covering 340,026 words, and the least was Media Indonesia with 176,097 words of 979 articles. 
Table 1. Number and Percentages of Articles and Words Downloaded from Three Newspapers

\begin{tabular}{|l|r|r|r|c|}
\cline { 2 - 5 } \multicolumn{1}{c|}{} & Nr. of texts & $\%$ & Nr. of words & $\%$ \\
\hline 1. Kompas & 1,264 & $34 \%$ & 340,026 & $33 \%$ \\
2. Koran Tempo & 1,428 & $39 \%$ & 525,074 & $50 \%$ \\
3. Media Indonesia & 979 & $27 \%$ & 176,097 & $17 \%$ \\
\hline \multicolumn{1}{|c}{ Total } & 3,671 & $100 \%$ & $1,041,197$ & $100 \%$ \\
\hline
\end{tabular}

From the description of the corpus content, the percentage of articles among those three newspapers might be said to be balanced in number though Media Indonesia was slightly less than $33 \%$. However, in number of texts it seems Koran Tempo dominating the corpus. Kompas is fairly representative in number of percentage, but Media Indonesia is really poor in percentage since it only covered one-sixth of total texts in the corpus.

From the corpus, the writer obtained the non-BI words with their frequencies. There were 7,687 words selected by the computer program in this category. After they were checked manually to look for English borrowings, it was found 3,538 words remained and these words were taken to fulfill the data of this study.

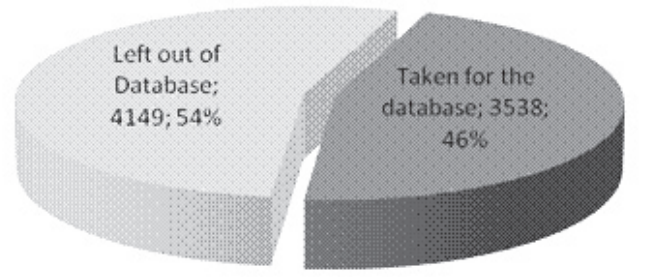

Figure 1. Number of Words Selected to Fulfill the Database

To elicit English borrowings from this database, the writer was guided by looking up the book of European loan-words in Indonesian: a check-list of words of European origin in Bahasa Indonesia and traditional Malay.

The distribution of lexical borrowings according to their characteristic established and non-established loansis described below based on the number of types and tokens with the percentage in the database.

Table 2. Number and Percentage of Lexical Borrowing Per Types and Tokens

\begin{tabular}{|l|l|l|l|l|}
\cline { 2 - 5 } \multicolumn{1}{c|}{} & Types & $\%$ & Tokens & $\%$ \\
\hline $\begin{array}{l}\text { Established } \\
\text { loans }\end{array}$ & 1,952 & $55 \%$ & 11,086 & $57 \%$ \\
\hline $\begin{array}{l}\text { Non- } \\
\text { established } \\
\text { loans }\end{array}$ & 1,586 & $45 \%$ & 8,408 & $43 \%$ \\
\hline Total & 3,538 & 100 & 19,494 & 100 \\
\hline
\end{tabular}

The overall results of lexical borrowing confirmed the difference among the loan characteristics is relatively high. The range percentage in types between established loans and non-established loans is $10 \%\left(\chi^{2}=37.862\right.$ or $p=.000)$ and in tokens is it a little bit higher with $14 \%\left(\chi^{2}=367.892\right.$ or $\left.p=.00\right)$. Both types and tokens values are significant at $5 \%$ level on a chi-square test. This suggests that there is no differences between types and tokens to represent the values of borrowing i.e., established loans and non-established ones.In this case, the writer sufficiently used number of types in borrowing other than tokens since the values of $\chi^{2}$ showed no difference. 
The distribution of lexical borrowings according to the integration or adaptation made in the receptor language shows that the concentration of English borrowing is not integrated linguistically into BI especially in nonestablished loans. It is different with established ones in which English is well-adapted into BI either orthographically or morphologically.

Table 3. Frequency and Percentage of Lexical Adaptation in English Loans by Number of Types

\begin{tabular}{llllc}
\hline Category of Adaptation & \multicolumn{2}{l}{ Established loans } & \multicolumn{2}{l}{ Non - established loans } \\
\hline no adaptation & 139 & $7.1 \%$ & 1,495 & $94,3 \%$ \\
\hline only orthographically adapted & 803 & $41.1 \%$ & 13 & $0.8 \%$ \\
\hline $\begin{array}{l}\text { orthographically and } \\
\text { morphologically adapted }\end{array}$ & 944 & $48.4 \%$ & 12 & $0.8 \%$ \\
\hline only morphologically adapted & 66 & $3.4 \%$ & 66 & $4.2 \%$ \\
\hline Total & 1,952 & $100 \%$ & 1,856 & $100 \%$ \\
\hline
\end{tabular}

Meanwhile, the distribution of lexical borrowings according to word classes shows that in established loans the percentage of nouns is more thantwo fold that of verbs, and the percentage of adjectives is the least in the hierarchy since there is no tokens in adverbs and prepositions.

\section{Table 4. Frequency of Established Loans Based on Adaptation and Word Categories}

\begin{tabular}{lllllll}
\hline & \multicolumn{3}{l}{ Word Categories } & & \\
\hline Categories of Adaptation & Noun & Verb & Adj & Adv & Prep & Other \\
\hline 1. without adaptation & 108 & 1 & 30 & 0 & 0 & 0 \\
\hline 2. only orthographically adapted & 574 & 14 & 215 & 0 & 0 & 0 \\
\hline 3. orthographically and morphologically adapted & 407 & 465 & 71 & 0 & 0 & 1 \\
\hline 4. only morphologically adapted & 18 & 6 & 42 & 0 & 0 & 0 \\
\hline \multicolumn{1}{c}{ Total number } & 1107 & 486 & 358 & 0 & 0 & 1 \\
\hline & $56.7 \%$ & $24.9 \%$ & $18.3 \%$ & $0 \%$ & $0 \%$ & $0,1 \%$ \\
\hline
\end{tabular}

On the other hand, in non-established loans the dominancy of nouns is not different with in the established one. There is an interesting change here because adjectives are more dominant than verbs where the number almost twice. Then, the other word classes are much higher in this kind of loans such as preposition and others. 
Table 5. Frequency of Non-established Loans Based on Adaptation and Word Categories

\begin{tabular}{lllllll}
\hline & \multicolumn{7}{l}{ Word Categories } & & \\
Categories of Adaptation & Noun & Verb & Adj & Adv & Prep & Other \\
1. without adaptation & 1026 & 126 & 278 & 15 & 11 & 39 \\
2. only orthographically adapted & 10 & 0 & 3 & 0 & 0 & 0 \\
$\begin{array}{l}\text { 3. orthographically and morphologically } \\
\text { adapted }\end{array}$ & 7 & 3 & 2 & 0 & 0 & 0 \\
4. only morphologically adapted & 35 & 29 & 2 & 0 & 0 & 0 \\
$\quad$ Total number & 1078 & 158 & 285 & 15 & 11 & 39 \\
$(\%)$ & $68,0 \%$ & $10,0 \%$ & $18,0 \%$ & $0,9 \%$ & $0,7 \%$ & $2,5 \%$ \\
\hline
\end{tabular}

It goes without saying, these percentages confirm that the hierarchy of borrow ability in established loan is nouns $>$ verbs $>$ adjectives $>$ adverbs and in non-established loan is nouns $>$ adjectives $>$ verbs $>$ adverbs. From this hierarchy, noun dominates both kinds of loan. This is actually a general phenomenon in lexical borrowing in which the primary motivation for lexical borrowing is that to extend the referential potential of a language. Since the reference is established primarily through nouns, this word category is borrowed most easily (Van Houtand Muysken, 1994).

\section{DISCUSSION}

\section{Linguistic Adaptation in Non-established Borrowings}

The number of English words borrowed into BI which is regarded without linguistic integration in non-established loans is very high where $94 \%$, and only approximately $6 \%$ English words borrowed in this type of loans is linguistically integrated (see Table 3). This phenomenon implies that Bahasa Indonesia highly tolerates the alien words in its linguistic repertoire.This is reasonable because there is no change of orthography or morphology to the loan words entering BI syntactical structure.

If it is looked into more specific by the word category, noun still occupies the highest rank of unadapted borrowing followed by adjective, verb, adverb and preposition (see Table 5). Almost $70 \%$ of borrowing in non-established loan which is unadapted into BI is dominated by noun $(1,026$ types). This is indicated that English nouns are really familiar and wellaccepted in BI speakers. Interestingly, there are fewer verbs unadapted than adjective. Though its number cannot reach the half number of noun, the adjective is able to quantify almost two fold of the verb. From this fact, verbs in English are less familiar than adjectives.

The other two word categories namely adverb and preposition are not more than one percent on each quantity to be borrowed without adaptation. Both may be borrowed less easily than the other content words such as nouns, verbs, and adjectives. This may be due tothose content words are most closely involved with the culture of a language so that they have a clear link to cultural content rather than function words (Van Hout\& Muysken, 1994).

The second characteristic that the writer remarks on the linguistic adaptation in English borrowing is that the word is adapted orthographically into BI lexicons. In orthographic adaptation, the words borrowed from English into BI experience the change of some orthography composition which is adapted into BI, e.g., manifest à manifes, triumvirate à triumvirat, ankle à ankel.This kind of adaptation, of course, is still not established into BI since itis not included into BI Dictionary yet, or even they are precisely not widespread. The number of borrowing in this kind of adaptation is really small only 13 types. In relation to the minimal frequency occured to this kind of adaptation, this may 
be fully understood that their forms have not been widespread and are not established yet in BI lexicons.

The third characteristic of linguistic integration which the writer remarks in this study is that wordschange orthographically and morphologically into BI lexicons. Since their forms are not established yet into BI, the number of this adaptation is also relatively small which only has 12 types or $0.01 \%$ of total types (see Table 3). This number shares in three word categories: noun, verb, and adjective. Interestingly, all types of noun which are orthographically and morphologically adapted into BI are mostly with the suffix -nya indicating possessive pronoun of third person singular, e.g., bodiguardnya (her bodyguard), stresnya (his stress), bloknya (his block) etc. The writer cannot detect the other nouns which are morphologically adapted with the other possessive pronouns such as first or second person singular because these pronouns do not attached with the free morpheme rather than in a separated word.

The fourth characteristic of adaptation is that English borrowings only adapt morphologically into BI. The number of borrowing in this adaption is little higher than the last two mentioned previously, it has 66 types. This number shares noun with 35 types of morphological adaptation, verb has 29 types and adjective has two types only (Table 5). Again,the writer remarksin nouns thatthe morphological adaptation is in the form of suffix-nya such as treatment-nya (its treatment), dress-nya (her dress), whereas in verbs there are some varied BI bound morphemes such as di-, me $(m)(n)(n g)-$, and ber, as indicharge (be charged), mem-backup (to back-up), mereset (to reset), menghighlight (to highlight), mendeliver (to deliver), ber-track (to have track) etc. This kind of adaptation is what Muysken (2000) termed as relexification where a process of grammatical restructuring between two languages including affixes from one language and lexical roots from the other language.

\section{Linguistic Adaptation in Established Borrowings}

The linguistic adaptation in established loans is not concentrated on one types of adaptation only, not like in non-established loan where mostly English borrowings are not adapted at all into BI (see Table 3).In established borowing, the percentage of English loan words which are not adapted into $\mathrm{BI}$ is about $7 \%$. From the table, it may be stated that more than $90 \%$ of loan words are integrated into BI by changing their orthographical and morphological forms. This phenomenon implies that loan words which are established into BI are highly motivated to integrate with BI linguistic form such as the orthography and the morphologycal forms.

In relation to word categories, nouns and adjectives seem flexible word categories in this type where they may integrate into BI lexicons without adaptation, not like verbs which are complex to integrate. This is actually due to the system of verb in BI which should have affixes to indicate an action doing something to put into the verb itself, such as me $(\mathrm{n} / \mathrm{ng} / \mathrm{m})-$, di-, and ber-). In BI, a verb may stand without the prefixes if it expresses a command. Therefore, in this type of integration almost none verb may stand without such prefixes. It goes without saying, the flexibility of established English verbs to integrate into BI context is not as easy as nouns or adjectives.

In the second type of adaptation where only orthographical element adapted.The noun is again the largest word class adapting into BI then followed by the adjective and the verb. In this type of adaptation, the percentage of English borrow ability is relatively high which is up to $41 \%$ (see Table 3). The linguistic system of BI, in fact, allows to borrowed foreign words with this type of adaptation by two techniques of loan: first, borrowing with the adaptability of spelling and pronunciation; second, borrowing with the adaptability of spelling but not the pronunciation (Moeliono et al., 2005). Therefore, the words in the database such as spesies, suporter, 
sistem, misteri, poin, etc., are loan words with the adaptability of spelling and pronunciation while words such as rilis, trek, syuting, stroberi, etc., are loan words with the adaptability of spelling but not the pronunciation.

Then, the third type of integration is loan words adapted orthographically and morphologically into BI system. This type of integration is not really different with the second typeof this loan. Verbs are more integrated orthographically and morphologically than nouns and adjectives. This is actually caused by a simple factor where verbs in BI need prefixes such as me-, men-, mem-, meng-, di-, and ber- to denote an action to do something. Established loan nouns which are adapted orthographically in BI are relatively high. Therefore, the loan nouns which are established are embeddedby prefixes to derive verb category. Number of verbs in this type of adaptation becomes the largest. To mention some, such as berkarir (to have a carrier) derived from a noun karir, mengkomplain (to complain) derived from a nounkomplain, dipoligami (to be married in polygamy) derived from a nounpoligami, bersistem (to have a system) derived from a nounsistem, and berargumen (to argue)derived from a nounargumen. These are nouns which firstly adapt orthographically then they integrate morphologically into BI by adding affixes to form verbs.

The last type of integration is the morphological adaptation without orthographical change from English words. In this case, the characteristic of borrowing refers to the established loan which only adapted morphologically into BI lexicons. There are 66 types in this characteristic of integration which are far less in amount than the three characteristics discussed before. Mostly loan words adapted into BI are remarked by adding clitic-nya into established nouns,e.g., videonya (his video), natriumnya (the content of natrium), arenanya (its arena); while in the verb category, loan words integrated are remarked by adding prefix ber-into noun category, e.g., berbikini (to wear bikini), bertempo (to have tempo).

\section{CONCLUSION}

Borrowing seems unseparable with the linguistic integration or adaptation. The writer notifies four linguistic integrations of English words borrowed into BI. Those are zero-adaptation of loan words, only orthographical adaptation of loan words, orthographical and morphological adaptation of loan words, and only morphological adaptation of loan words. From those four types of integration, English tends to adapt mostly its lexicons into BI by morphological adaptation if the loan words are regarded as the established borrowing. However, when the loan words are non-established (or nonce borrowing) there is mostly no adaptation at all to be made dealing with the morphological integration. In this case, the loan words are really alien among BI lexicons when there is no adaptation made. In relation with the morphological integration, the writernotifies a phenomenon of borrowing in which Muysken (2000) termed it as 'relexification' where a process of grammatical restructuring between two languages including affixes from one language and lexical roots from the other language. Morphological adaptation of English into BI bears many relexification forms in its borrowing typology, such as BI-Prefix + Engword, or Eng-word + BI-suffix.

To conclude, the borrow ability of noun is higher than the other three content words: verb, adjective, and adverb in both typologies of borrowing, but verb and adjective replace each other for the second largest in both typologies. Meanwhile, the linguistic integration tends to be dominated by orthographical and morphological adaptation in established borrowings and be dominated by zero adaptation in nonestablished borrowings.In this regard, types of borrowing are determined by word classes where $\chi^{2}$ approximation for the Chi-square test resulting $\chi^{2}=188.687$ with $p$-value $=.000(a=$ .05) $\mathrm{df}=4$. Since the $p$-value is less than $\alpha=$ .05 , the writer may conclude that the types of borrowing depends on the types of word class. This means not all word categories of English can be borrowed into BI, or only certain word categories can be borrowed. 
Then, this study proves that the linguistic adaptation is decided by the typology of borrowing. This is defined by the $\chi^{2}$ approximation for the Chi-square test resulting $\chi^{2}=2790.731$ with $p$-value $=.000(a=.05) d f=3$. Since the $p$-value is less than $\alpha=.05$, the writer has a reason to summarize thatthere is a sufficient evidence to indicate that the typology of borrowing (established and non-established) determines the types of linguistic adaptation.

\section{REFERENCES}

Clyne, M. (2003). Dynamics of Language Contact: English and Immigrant Languages. Cambridge: CUP.

Grosjean, F. (1995). A Psycholinguistic Approach to Code-Switching. In Milroy and Muysken, 259-275.

Haugen, E. (1950). The Analysis of Linguistic Borrowing. Language. 26, 210-231.

Jones, R., (Ed). (1983). European LoanWords in Indonesian: Acheck-List of Words of European Origin in Bahasa Indonesia and Traditional Malay. In Indonesian Etymological Project. KoninklijkInstituutvoorTaal-, Land-en Volkenkunde, Leiden.

King, R.E. (2000). The Lexical Basis of Grammatical Borrowing: A Prince Edward Island French Case Study. Amsterdam, Philladelphia: John Benjamins.

Mesthrie, R. \& Leap, W.L. (2000). Language Contact 1: Maintenance, Shift and Death. In Introducing Sociolinguistics. (Ed.). Mesthrie, R., Swann, J., Deumert, A., and Leap, WL. Edinburgh: Edinburgh University Press.

Moeliono, A.M., Rifai, M.A., Zabadi, F., \& Sugono, D. (2005). Pedoman Umum Pembentukan Istilah. Jakarta: Pusat Bahasa, Departemen Pendidikan Nasional.

Muysken, P. (2000) Bilingual Speech: A Typology of Code-Mixing. Cambridge: Cambridge University Press.
Last, word categories give significant contribution to motivate the linguistic adaptation. This is proved by the value of $\chi^{2}$ approximation where $\chi^{2}=907.00$ with $p$-value $=.000(\alpha=.05) \mathrm{df}$ $=6$. Since the $p$-value is less than $\alpha=.05$. The writer implies that word categoriesEnglish loan wordsmotivate the linguistic adaptation in BI lexicons.

Onysko, A. (2007). Anglicism in German: Borrowing, Lexical Productivity, and Written Codeswitching. Berlin, New York: Walter de Gruyter.

Poplack, S. \& Meechan, M. (1995). Patterns of Language Mixture: Nominal Structure in Wolof-French and Fongbe-French Bilingual Discourse. In Milroy and Muysken, 199-233.

Poplack, S. \& Meechan, M. (1998). Introduction: How Languages Fit together in Codemixing. International Journal of Bilingualism, 2, 127-38.

Poplack, S., Sankoff, D. \& Miller, C. (1988). The Social Correlates and Linguistic Processes of Lexical Borrowing and Assimilation. Linguistics, 26: 47-104

Roksana, B.A. (1995). Kata-kata Inggeris dalam Akhbar Melayu di Singapura: Kekurangan Bahasa Melayu dan Ketidakpekaan Wartawan? Jurnal Dewan Bahasa, 713-717.

Sankoff, D., Poplack, S. \& Vanniarajan, S. (1990). The Case of the Nonce Loan in Tamil. Language Variation and Change, 2, 71-101

Shamimah, B.H.M. (2006). A Study of English Loan Words in Selected Bahasa Melayu Newspaper Articles. Kuala Lumpur: International Islamic University Malaysia.

Sundari, L. (2005). The Use of English Loan Words in the Komunikasi Bisnis Section 
of Jawa Pos. Bachelor Thesis, Surabaya: Faculty of Letters, Petra Christian University Surabaya.

Van, H.R. \& Muysken, P. (1994). Modeling Lexical Borrow Ability. Language Variation and Change, 6, 39-62. http:/ /id.wikipedia.org/wiki/Koran_ Kompas\#Sejarah http://id.wikipedia.org/wiki/Majalah_ Tempo

http:/ / www.mediaindonesia.com/Sejarah_ Singkat 
